\title{
LATVIAN STUDENTS' UNDERSTANDING OF GLOBAL PROBLEMS AND READINESS TO GET INVOLVED IN SOLVING THEM IN OECD PISA 2018 COMPARISON
}

\author{
Andris Kangro, Rita Kiselova \\ University of Latvia, Latvia
}

\begin{abstract}
Students' life in the modern globalized world gives them many new possibilities and at the same time also creates new serious challenges putting forward also new requirements. Students' understanding of the global problems (climate changes and global warming, global health (including pandemics), migration, international conflicts, famine or insufficient food, the causes of poverty, etc.) become more and more important. The aim of the study is to analyze the results of Latvia's fifteen years old students in the OECD PISA 2018 in the aspect of the global competence paying a more detailed attention to the students' understanding of the global problems and their readiness to take action for collective wellbeing. The research questions are follows: 1) What is Latvian students' global competence in the international comparison and what is its relation to the characteristics of students, their families and school; 2) What is Latvian students' understanding of the global problems and readiness to get involved in their solution? The descriptive statistical analysis employs the data from surveys/questionnaires (66 countries) and tests (27 countries) included in PISA 2018 international data basis. Latvian students' performance in the cognitive test of the global competence is considerably higher than the average of the participating countries, and as regards the OECD countries we are on the average level. In Latvia, students of capital Riga schools have the highest level of global understanding, it is lower in other cities and even lower in rural schools. Latvian students have a slightly lower readiness to get involved in solving the global phenomena and participation in concrete activities than the average in OECD countries.
\end{abstract}

Keywords: global competence, intercultural interaction, OECD PISA, students ` performance, sustainable development.

\section{Introduction}

Globalization means an ever faster and more intensive flow of people, capital, goods, ideas and technologies among countries and regions. These 
globalization processes will influence more and more the economics and culture of the countries and the environment in the whole world. Therefore it is crucial to understand what our young people should know and be able to do so that they are better prepared for the life in the globalized world (Sahlberg \& Brown, 2017). Theoretical approaches and definitions are developed, the respective themes and teaching/learning methods are updated in the curriculum so that then to assess to what extent the global competence is developed in students and then give recommendations. OECD PISA 2018 study had developed and applied the innovative assessment module of students' global competence.

The aim of the study is to explore the global competence of Latvia's fifteen years old students in the PISA 2018 comparison paying special attention to the students' understanding of the global problems and their readiness to get involved in solving them. The young people need to be informed, they must have the understanding of the global problems that influence significantly the life of current and future generations in the whole world so that they could form their life, which means also engaging in promoting the development of the society and sustainable environment.

\section{Theoretical background and previous research}

The OECD PISA 2018 study measures the fifteen years old students' understanding of the global problems and their readiness to get involved in solving them as part of the global competence. The global competence in PISA 2018 study is defined as a multidimensional capacity that encompasses the ability to: 1) examine issues of local, global and cultural significance; 2) understand and appreciate the perspectives and world views of others; 3) engage in open, appropriate and effective interactions across cultures; and 4) take action for collective well-being and sustainable development (Organisation for Economic Co-operation and Development (OECD), 2019; OECD, 2020). In turn, the definition developed by the Council of Chief State School Officers of the United States and Asia Society in the project about the acquisition of the global competence at school underlines, in particular, the competence to understand and solve problems of global importance, "Global competence is the capacity and disposition to understand and act on issues of global significance" (Boix-Mansilla \& Jackson, 2011); however, a bit later both the mentioned definitions are combined (OECD/ Asia Society, 2018). Global Competence Associates consider that the global competence implies the ability to interact positively and effectively with anyone in the world; it has also developed the global competence model according to the definition "Having flexible, respectful attitudes, including self-perspective, and applying knowledge of the historical, geographic, and 
societal factors that influence cultures in order to effectively interact and build relationships with people around the world" (Hunter et al., 2006; Hunter, 2004). The mentioned authors have also developed a tool to measure the global competence based on the surveys - The Global Competence Aptitude Assessment (GCAA $®$ ), which is Web-administered and accessible from any location in the world. However, the authors consider that it can be used only for people older than fifteen therefore the studies and their results are applied in upper secondary schools, higher education institutions, enterprises and offices. This definition of global competence does not directly include such global issues as the environment, world hunger and famine, the spread of HIV/AIDS, the availability of clean water, social justices etc. (https://globallycompetent.com/assessment/), which, in principle, were incorporated in the two approaches previously looked upon.

The Council of Europe has adopted the "Maastricht Global Education Declaration" "Reference Framework of competences for Democratic Culture: Policy context, content and impact" and has developed a set of policy documents of different other levels as well as a full set of tools for introducing global education in different stages of education. These documents and materials provide the following definition "Global Education is education that opens people's eyes and minds to the realities of the world, and awakens them to bring about a world of greater justice, equity and human rights for all" a conceptual model of democratic and intercultural competence, which, all in all, consists of 20 elements (skills, knowledge and critical understanding, attitudes and values) is also offered (Barrett, 2020; Council of Europe, 2018; Huber \& Reynolds, 2014; O'Loughlin \& Wegimont, 2002). The Council of Europe materials note that Global Education incorporates many global dimensions of the Education for Citizenship (Intercultural Education, Human Right Education, Education for Peace and Conflict Prevention, Education for Sustainability, Development Education).

UNESCO, too, develops documents and guidelines in this field, mainly, using the concept "global citizenship education" the conceptual dimensions of which are, for instance, "to acquire knowledge, understanding and critical thinking about global issues, to act effectively and responsibly for a more peaceful and sustainable world" (United Nations Educational, Scientific and Cultural Organization (UNESCO), 2015a) that coincides with several global education dimensions discussed above. Global citizenship education and education for sustainable development are mentioned also as the foundation for measuring concrete indicators. This is also topical in the program of the United Nations 2030 Sustainable Development Goals (SDGs) (for example, percentage of students by age group (or education level) showing adequate understanding of issues relating to global citizenship and sustainability, Target 4.7. Indicators Framework) (UNESCO, 2015 b). 
The term global competence is relatively new but many related fields have been developed in even longer period of time (Hunter et al., 2006; Buckner \& Russell, 2013). There are still discussions going on; there is not a common theoretical approach to the concepts of global competence and global citizenship, and the respective framework and constructs for measurement (Gardinier, 2021; Dill, 2018; Sälzer \& Roczen, 2018; Engel et al., 2016; Torres, 2015; Davies et al., 2005; Kymlicka, 2003). Studies continue about the current situation in the field of global competence, global citizenship and related fields as well as improving it in schools (Biseth et al., 2021; Nguyen, 2018; Chou et al., 2015; Buckner \& Russell, 2013), in higher education (Liu et al., 2020; Menga et al., 2017; Torney-Purta et al., 2015) and, especially, in teacher education (Bordeianu, 2019). Researchers from the University of Tel Aviv (Goren \& Yemini, 2017) have performed the comparative analysis of many empirical studies in the field of global citizenship in schools.

The International Association for the Evaluation of Educational Achievement (IEA) together with more than 60 countries of the world implements already the fifth cycle of citizenship education study, namely, International Civic and Citizenship Education Study (ICCS 2022) (https:// www.iea.nl/ ). Since 1997, Latvia has participated already in four of these cycles - CIVED, ICCS 2009, ICCS 2016, ICCS 2022 (Kangro, 2003; Čekse et al., 2010 a; Čekse et al., 2010 b; Čekse et al., 2017). The content of ICCS 2016 includes civic society and systems, principles, participation and identities (Schulz et al., 2016). When participating in the study, students fill in the test and a questionnaire; their teachers and school directors, too, fill in the questionnaires. The performance of Latvian students in ICCS tests is lower than the average of the participating countries. The results of the global competence module of ICCS and PISA 2018 cannot be compared directly because the framework of studies, the composition of the participating countries, to a certain extent, are different. The participants of the ICSS are Grade 8 students but the participants of the PISA study are, mainly, Grade 9 students.

The explored approaches and studies include ideas that the global competence has to be developed in the context of lifelong education as it is vital both in the modern labor market and in ensuring sustainable development of the society. Certainly, it is exactly the school education stage that plays a huge role in the formation of the global competence. Global competence in schools is developed both as transversal skills (civic participation, cooperation, critical thinking etc.), and in the social and civic, natural sciences, languages and others fields of studies (Boix-Mansilla \& Jackson, 2011; Council of Europe, 2018; Chou et al., 2015; Regulations Regarding the State Basic Education Standard and Model Basic Education Programmes, 2018; 
Recommendations on placing development/global education on school agenda, 2015). Of course, also many out-of-school extracurricular factors impact profoundly students' global competence, namely, the opinions of the peers, family members as well as opinions expressed in the society, etc. (Schulz et al., 2008).

It has been discussed that different definitions of the global competence include both the understanding and attitude to the topical modern problems in ensuring sustainable development of the society and environment and the issues of intercultural interaction (OECD, 2019), although the different approaches have emphasized either one or the other of these aspects.

\section{Methodology}

In order to explore the Latvian fifteen years old students' understanding of the global competence, its separate aspects and relation with different factors in view of the PISA 2018 study, the following research questions were put forward: 1) What is Latvian students' global competence in the international comparison and what is its relation to the characteristics of students, their families and school; 2) What is Latvian students' understanding of the global problems (climate change, global health (e. g. epidemics), migration, international conflicts, hunger, causes of poverty, equality between men and women) and readiness to get involved in their solution? The methods used in the study are the literature analysis for defining the theoretical approaches to global competence, for identifying its nature and previous studies in this field, the procuring of specific results for Latvia based on the analysis of students' performance in the PISA 2018 cognitive test and the opinions expressed in students' and school directors' questionnaires applying the descriptive statistical methods and the PISA 2018 international data basis (https://www.oecd.org/pisa/data/2018database/).

The participants from Latvia in the main study of PISA 2018 were 5985 students from 308 schools, who resulting from the statistical sampling represented 16107 fifteen years old (born in 2002) students who attend different educational institutions of Latvia (except special education institutions) no lower than Grade 7. PISA participants are mainly students of Grade 9 (86\%). The PISA 2018 global competence module test was completed by students from 27 countries of the world (including 11 OECD countries), the respective students' questionnaire, in turn, was filled in by students from 66 countries.

The approach used in the PISA 2018 study for assessing the four dimensions of the global competence mentioned above is presented in Figure 1 (OECD, 2019). The cognitive test has been developed to assess students' understanding of the global problems. According to the definition developed 
in the PISA 2018 study (OECD, 2019) the construct "global understanding" includes both the knowledge about global and intercultural problems and 4 groups of cognitive skills that the student needs to fulfil successfully the test items. These groups of cognitive skills include the capacity to: 1) evaluate information, formulate arguments and explain complex situations and problems, 2) identify and analyze multiple perspectives and world views, 3) understand differences in communication in diverse cultural contexts, 4) evaluate actions towards sustainable development (OECD, 2019).

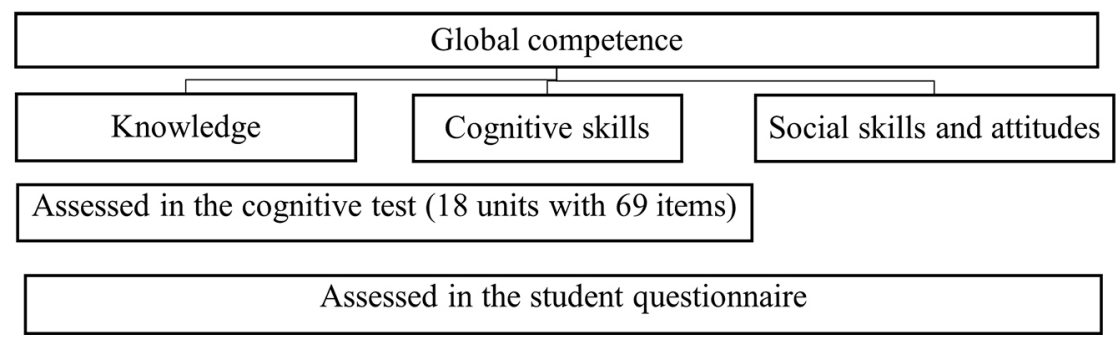

Figure 1. The PISA 2018 approach to assessing global competence (OECD, 2019)

As always in PISA tests, each test unit is based on the scenario after reading which the student answers the test items. Each of the scenarios of 18 units of the cognitive test corresponds to one of the content domains: 1) Culture and intercultural relations, 2) Socio-economic development and interdependence, 3) Environmental sustainability, 4) Institutions, conflicts and human rights (OECD, 2019). The test is computerized, 5 test units are available for on-line completion in different languages (also Latvian and Russian) in the OECD PISA home page (https://www.oecd.org/pisa/test/ other-languages/pisa-2018-global-competence-test-questions.htm), and the rest of items of the global competence module of the PISA 2018 basic study are confidential. Latvian students completed the test items either in Latvian or in Russian depending on the language of instruction in school. Regarding the response format, the tasks contain both simple multiple choice items, complex multiple choice items, and open-response items.

Including a new PISA study content domain for the first time, a scale is developed for assessing student performance where the mean value of student performance of OECD countries is 500 points and standard deviation is 100 points, and the average performance of participating countries is compared with this average indicator. However, as the cognitive test of the global competence module was done only by students of 27 countries and only 11 of them were OECD countries, then the mean value of student performance in all participating countries, which is 474 points and standard deviation - 91 points, is used for the international comparison. 


\section{Results and discussion}

The performance of Latvian students in the cognitive test of the global competence (497 points, standard deviation 84) is considerably higher than the average level (474 points) and considering all 27 countries participating in the test we take the $9^{\text {th }}$ place. The top performing students are in Singapore, Canada and Hong Kong (China). In turn, in relation to the 11 OECD countries that participate in the test, we actually are on the average level. $42 \%$ of Latvian students, in turn, have given correct answers to those 37 test items, which correspond to the first dimension of the OECD global competence definition - students` ability to examine local, global and intercultural issues. The percentage of correct answers given by students of OECD countries to these test items is also $42 \%$, but the result of all countries participating in the test is lower - 38\% (OECD, 2020).

Although results of the IEA civic education study (IEA ICCS 2016) and PISA 2018 global competence module are not directly comparable, among 10 countries that participated in both studies Latvia is the only country in which the student performance in ICCS 2016 is significantly lower than the average indicator of the participating countries (Schulz et al., 2018), but in PISA 2018 global competence module - significantly higher than the average of participating countries. The explanation of this fact can be that participants of ICCS are Grade 8 students while in PISA - mainly (86\% of all participants) Grade 9 students, and topics of civic education are mainly incorporated in the Grade 9 curriculum.

There is a high, statistically significant correlation (see Table 1) among the student performance in all PISA 2018 content domains, both on average in all participating countries and Latvia. The global competence performance of Latvian students has the highest correlation with the performance in reading (higher than the average of OECD countries). For our students a one-unit increase in the index of students' enjoyment of reading is associated with an increase of 25 points in the global competence performance. The high correlation of the global competence performance with the reading performance could be explained also by the considerable difference (32 points) between girls' (512 points) and boys' (480 points) mean performance in the global competence test, in reading the girls' performance is by 33 points higher than the boys' performance.

Similar to other PISA content domains student performance in the global competence test, too, depends on the social economic status (ESCS) of the student's family in all countries participating in the study. In Latvia, the performance of students from families in the bottom quarter of ESCS on average is 465 points, in the top quarter - 529 points, the average in all participating countries is 440 points un 516 points, respectively. 
Table 1. Correlation of students' performance in global competence and in other PISA subjects

\begin{tabular}{|c|c|c|c|}
\hline \multicolumn{3}{|c|}{ Correlation between performance in ... } & \multirow[b]{2}{*}{$\ldots$ and performance in ... } \\
\hline Mathematics & Reading & Science & \\
\hline \multirow[t]{3}{*}{0.73} & 0.84 & 0.79 & Global competence \\
\hline & 0.79 & 0.78 & Mathematics \\
\hline & & 0.85 & Reading \\
\hline \multicolumn{3}{|c|}{ Correlation between performance in ... } & \\
\hline Mathematics & Reading & Science & $\ldots$ and performance in ... \\
\hline \multirow[t]{3}{*}{0.75} & 0.86 & 0.80 & Global competence \\
\hline & 0.78 & 0.77 & Mathematics \\
\hline & & 0.83 & Reading \\
\hline
\end{tabular}

Thus, in Latvia the impact of ESCS on student performance is slightly lower than in the countries participating in the study on average (the performance of students with high ESCS is, respectively, higher by 64 points in Latvia and by 76 points on average in participating countries). The relation of performance to ESCS of students' families influences also the distribution of Latvian student performance by the location of the school (see Fig. 2). In Figure 2, the average ESCS of school groups is expressed in z-scale with Latvian mean value 0 and standard deviation 1 . The student performance of Riga schools is significantly higher in all content domains (subjects) than the student performance in rural schools. It should be noted that in global competence the student performance of rural schools is the highest in comparison with other subjects. The difference in performance between Riga and rural students, in turn, is explicitly higher exactly in reading.

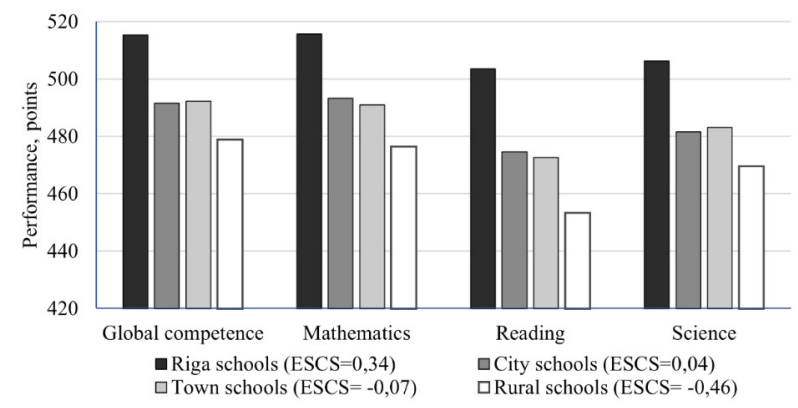

Figure 2. The average mathematics, science, reading and global competence performance distribution of Latvian students according to school location, PISA 2018 
Analyzing Latvian students' awareness about their knowledge regarding global issues, it is evident that our students feel less informed about the given issues than students of OECD countries on average (see Fig. 3).

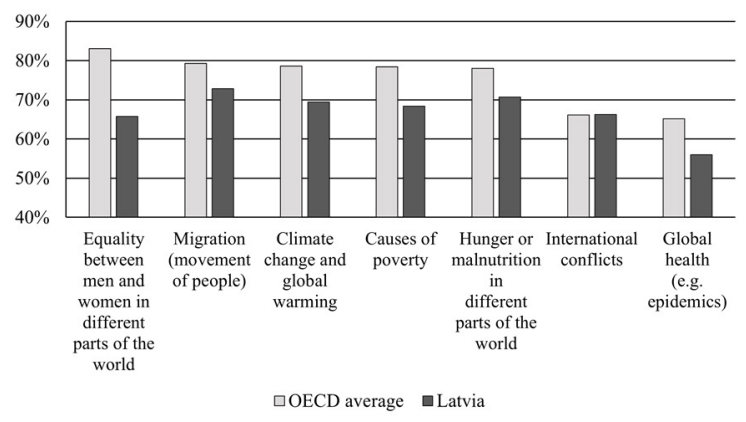

Figure 3. Students' awareness of global issues, by topic (Students who reported knowing about or being very familiar with the following topics)

Latvian students admit that they are the least informed about the currently due to the pandemic most topical issue - global health (e. g. epidemics), but the greatest difference in comparison with the average of the OECD countries appears in our students' awareness of the equality between men and women in different parts of the world (the difference is 17 percentage points). In the school survey, school principals in Latvia ( $90 \%$ and more), in turn, more frequently than school principals of OECD countries on average have answered that these topics are included in the school curricula. In Latvia, as well as in Estonia, Lithuania and 13 other OECD countries, there are no statistically significant differences in students' awareness of the given global topics in relation to the inclusion of these topics in the school curriculum (OECD, 2020). Thus, the opinion of Latvian school principals in this question is too optimistic, the mentioned results prove that both in Latvia and many other countries the opinions of school principals and students about the teaching/learning content that is planned and acquired differs. Consequently, not all topics are paid enough attention to in the teaching/learning process at school, most likely Latvian students have learnt the information about some of these topics outside the school. For instance, the sample programme of Latvian Social science subject (https://www.visc.gov.lv/lv/media/2695/ download), according to which PISA 2018 participants learnt, in Grade 9 only four lessons are envisaged for the topic "Care about the environment" and only two lessons for developing the understanding of the global process and forms of its expression in Latvia and in the world. In turn, the new sample programme of Social science for Grade 9 envisages 9 lessons for acquiring the topic "How to use sustainably the advantages 
of globalization and diminish its threats?" (https://mape.skola2030.lv/ resources/200). Problems connected with teaching the globalization-related topics at school were established already in PISA 2015 study where answering the question on how interesting it was to learn about ecosystems and sustainability in science lessons at school, only $37 \%$ of Latvian students answered that it was interesting or very interesting (Geske et al., 2020).

Latvian students' awareness of globalization-related topics is very closely linked (correlation 0.55) with students' conviction about their self-efficacy to perform certain tasks of the global competence (see Fig. 4). Latvian students as well as students of OECD countries (80\% and $77 \%$, respectively) consider that it is best to discuss different reasons why people decide to become refugees, and the least convinced (in Latvia 52\%, on average in OECD countries 58\% students) that they can establish a connection between prices of textiles and working conditions. Both in Latvia and on average in OECD countries, only approximately $60 \%$ of students could explain and discuss the consequences of the economic development on the surrounding environment and the influence of the carbon dioxide emission on climate changes in the world. This means that $40 \%$ of our students lack sufficient knowledge and understanding of these topics that are included in the content of science subjects.

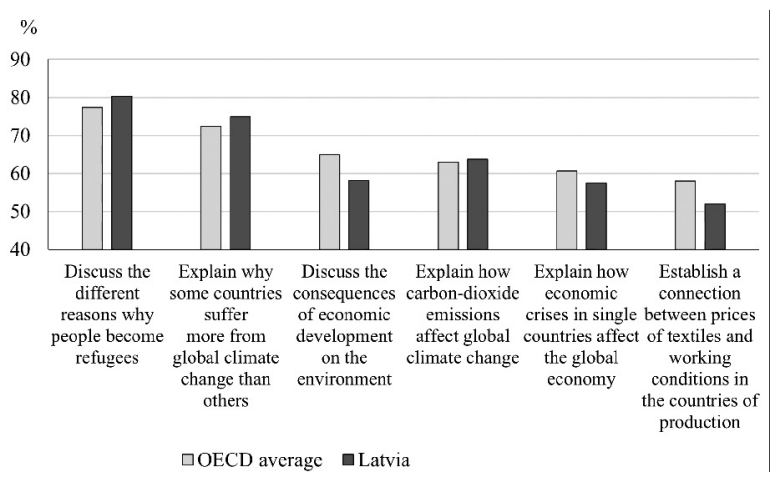

Figure 4. Students' self-efficacy regarding global issues, by task (Students who reported doing these tasks easily or with some effort)

Also the distribution of the number of students' responses "yes" and "no" by task, whether you acquire the further listed at school, shows that relatively seldom world events are discussed or analyzed at school during the lessons; students rarely are invited/encouraged to express their opinion or participate in discussions (see Fig. 5). In comparison with the average of OECD countries, Latvian students are less frequently invited or participate in these activities. 


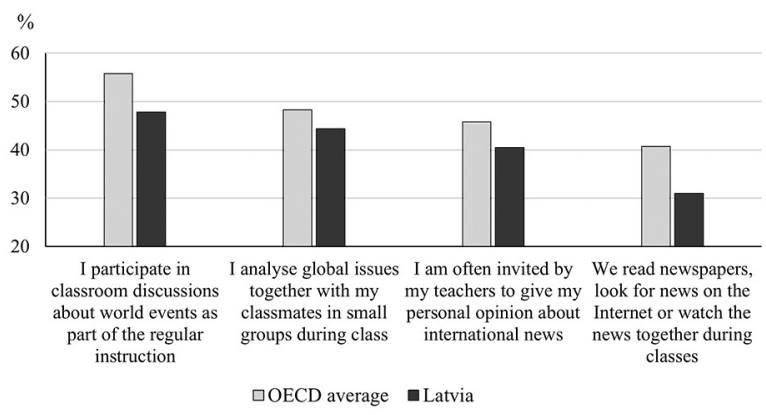

Figure 5. Students who reported learning the following at school

Students' questionnaire inquires not only about their knowledge and understanding of different problems related to globalization and sustainability but also their willingness, readiness and real engagement in solving these problems. $71 \%$ of Latvian students and $76 \%$ students on average in OECD countries consider themselves citizens of the world and admit that it is important to look after the global environment (see Fig. 6). In turn, less than a half of Latvian students (43-45\%) consider that they are able to do something to diminish the problems of the world and that their behavior can impact people in other countries. Students of OECD countries are more certain about their capacity to influence global problems (56-57\%). Probably, the relatively lower number of positive answers to these questions in Latvia and OECD countries can be explained by the age of the students, they do not yet feel mature enough to influence the world's problems and people. Although the example of Swedish environmental activist, school girl Greta Thunberg, proves the opposite.

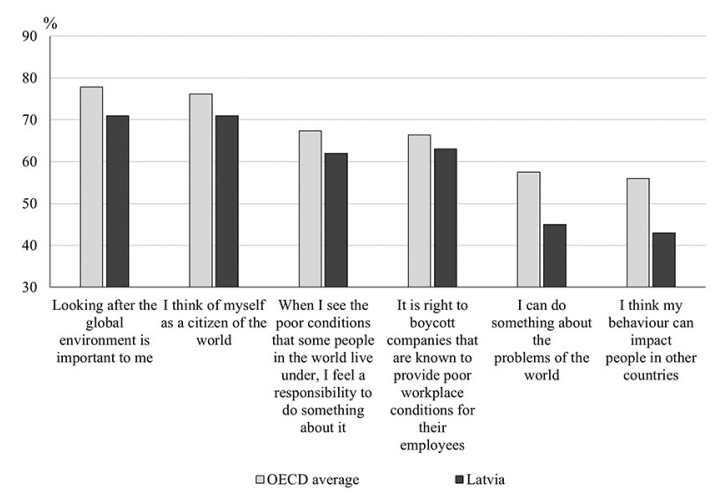

Figure 6. Students' agency regarding global issues, by attitudes towards those issues (Students who agreed or strongly agreed with the following statements) 
Regarding activities included in the survey, in which students could engage to promote sustainable development and common well-being (see Fig. 7), Latvian students as well as students of OECD countries have mentioned that they most frequently reduce the energy consumption (56\% and $71 \%$, respectively). Most seldom, only one fifth of our students participate in activities that promote equality between men and women and/or boycott goods or producers, there are more such students in OECD countries (33\% and 27\%, respectively). The equality between men and women is also a topic which our students consider to be less informed about (see Fig. 3).

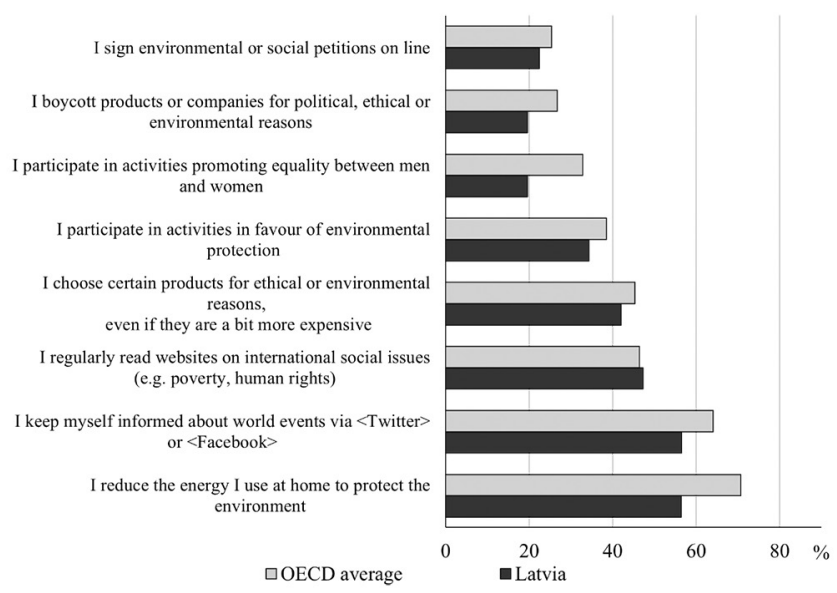

Figure 7. Students' capacity to take actions for common well-being and sustainable development

Both students of OECD countries in general and Latvian students more frequently have indicated that they follow different events in the world in Twitter and Facebook, but they read less the information in the internet sites, thus the awareness and knowledge of our students about globalization processes, probably, is more based on the opinions of their peers and the society than the objective information.

\section{Conclusions}

- Research sources surveyed in the study, including theoretical approaches and study materials developed by important international organizations, as well as the OECD PISA 2018 addressing the development of an innovative module for assessing students' global competence and using it in the study, show that education of today's young people for a full-fledged life in the global world is continuously in the focus of 
attention of researchers, developers of the teaching/learning content and teachers, and many research works and everyday pedagogical work is devoted to this.

- The average performance of Latvian 15-year-old students in the OECD PISA 2018 global competence cognitive test is generally quite similar to their performance in mathematics, science and reading tests - we are at the OECD average (significantly above the average of all countries participating in study). In Latvia, the highest performance of students is in the capital Riga, followed by other cities and towns, but the lowest is for students in rural areas.

- The OECD PISA study always shows a high correlation between students' performance in different content areas. The highest correlation with the results of the global competence cognitive test is directly with the results of the reading test ( 0.86 for Latvian students), also the index of students' enjoyment of reading is positively associated with global competence performance. As with reading, girls perform better than boys in the global competency test.

- Principals of Latvian schools more often than on average in OECD express the opinion about including different global issues in the school curricula (respectively, $98-90 \%$ and $88-78 \%$, depending on the concrete theme); however, it has to be mentioned that in Latvia and other 13 OECD countries (including Estonia and Lithuania) students' answers are not statistically significantly connected with that. Thus, the opinion of Latvian school principals in this question is too optimistic; the given results prove that both in Latvia and many other countries the opinions of school principals and students about the planned and implemented, and the acquired study curriculum differ.

- $56 \%$ to $73 \%$ of Latvian students consider that they now or are very familiar with many global issues (climate change, global health (e. g. epidemics), migration, international conflicts, hunger, causes of poverty, equality between men and women). The respective average indicators in OECD countries are higher; however, the Latvian students' self-efficacy regarding their ability to perform concrete tasks in relation to global problems (e. g., to explain concrete phenomena, to discuss their causes, etc.) is very close to the average indicators of OECD countries $50-80 \%$ of students are convinced that they will be able to do this. The compliance between Latvian students' opinions about their awareness of different global issues and the self- efficacy about their abilities to explain them in more detail is good (correlation is 0.55).

- Approximately $40 \%$ to $70 \%$ of Latvian students confirm their understanding of global issues and at the same time express their readiness to get involved in their solution. The greatest majority of students (71\%) 
express support to the care for the global environment, less than a half (43-45\%) - to the conviction about their capacity to diminish the problems of the world and with their behavior to influence people in other countries. The number of positive answers given by our students is only by $3-13$ percentage points (depending on the concrete item) lower that the average of OECD countries.

- $20-55 \%$ of Latvian 15-year - old students engage in different activities to promote sustainable development and common wellbeing, which in general is slightly below the average in OECD countries. The most, Latvian students reduce the energy consumption at home to protect the environment, the least - they boycott products or companies for political, ethical or environmental reasons or participate in activities promoting equality between men and women.

- The analysis of the data of PISA 2018 global competence module demonstrates that Latvian students display greater understanding and engagement exactly in relation to issues and activities of preserving the environment, lower - in relation to intercultural issues and problems that could be the direction of further research. The preliminary analysis shows that global competence topics are more represented in the new teaching/learning content, yet the implementation of the new teaching/ learning content - the teachers' work - will define the outcome.

\section{References}

Barrett, M. (2020). The Council of Europe's Reference Framework of competences for Democratic Culture: Policy context, content and impact. London Review of Education, 18(1): 1-17. https://doi.org/10.18546/LRE.18.1.01

Biseth, H., Hoskins, B., Huang, L. (eds.) (2021). Northern Lights on Civic and Citizenship Education: A Cross-national Comparison of Nordic Data from ICCS. Springer. https://www. springer.com/gp/book/9783030667870

Boix-Mansilla, V., Jackson A. (2011). Educating for Global Competence: Preparing Our Youth to Engage the World. Council of Chief State School Officers, Washington, DC https://asiasociety.org/files/book-globalcompetence.pdf

Bordeianu, A. D. (2019). Exploring global competencies for future educators: investigating students' global competency level in teacher preparation programs - traditional versus global education. [PhD dissertation in Education: Educational leadership, Oakland University, Rochester, Michigan]. ProQuest.

Buckner E., Russell, S. G. (2013). Portraying the Global: Cross-national Trends in Textbooks' Portrayal of Globalization and Global Citizenship. International Studies Quarterly 57, 738-750.

Čekse, I., Geske, A., Grīnfelds, A., Kangro, A. (2010b). Skolēnu pilsoniskā izglītïba Latvijā un pasaule. Starptautiskā pētijuma IEA ICCS pirmie rezultāti [Civic education of students in Latvia and in the world. First results of the international study IEA ICCS 2009]. SIA Drukātava, Rīga, https://www.ipi.lu.lv/publikacijas-1/iea-iccs/ 
Čekse, I., Geske, A., Grīnfelds, A., Kangro, A. (2010a). Latvijas skolēnu pilsoniskā izglitīiba un identitāte Eiropā. Starptautiskās pilsoniskās izglītibas IEA ICCS 2009 pētijuma Eiropas modula pirmie rezultāti. [Civic education and identity of Latvian students in Europe. First results of the European module of the international IEA ICCS 2009]. Riga, LU Akadēmiskais apgāds. https://www.ipi.lu.lv/publikacijas-1/iea-iccs/

Čekse, I., Geske, A., Pole, O. (2017). Pilsoniskās izglīibas problēmas un izaicinājumi. Starptautiskā pētijuma IEA ICCS 2016 pirmie rezultāti [Problems and Challenges of Civic Education. First results of the international study IEA ICCS 2016]. Rìga: Izglititibas pētniecības institūts. https://www.ipi.lu.lv/publikacijas-1/iea-iccs/

Chou, P.-I., Cheng, M.-C., Lin, Y.-L., Wang, Y.-T. (2015). Establishing the Core Concepts and Competence Indicators of Global/International Education for Taiwan's Grade 1-9 Curriculum Guidelines, Asia-Pacific Edu. Res., 24(4):669-678, DOI 10.1007/s40299-014-0215-0.

Council of Europe (2018). Reference Framework of Competences for Democratic Culture. Volume https://www.coe.int/en/web/reference-framework-of-competences-for-democratic-culture/rfcdc-volumes

Davies, I., Evans, M. \& Reid, A. (2005). Globalising Citizenship Education? A Critique of 'Global Education' and 'Citizenship Education', British Journal of Educational Studies, 53(1), 66-89, DOI: 10.1111/j.1467-8527.2005.00284.x

Dill, J. (2018). Global citizenship education: a critical introduction to key concepts and debates, British Journal of Educational Studies, 66(4), 559-560, DOI: 10.1080/ 00071005.2018.1529954

Engel, L. C., Fundalinski, J., Cannon, T. (2016). Global Citizenship Education at a Local Level: A Comparative Analysis of Four U.S. Urban Districts, Revista Española de Educación Comparada, 28, 23-51 DOI: 10.5944/reec.28.2016.17095

Gardinier, M. P. (2021). Imagining globally competent learners: experts and education policy- making beyond the nation-state, Comparative Education, 57(1), 130-146, DOI: 10.1080/03050068.2020.1845064

Geske, A., Grīnfelds, A., Kangro, A., Kisel̦ova, R., Stūre, B. (2020). Latvijas skolēnu sasniegumi un skolas vide OECD PISA salidzinājumā [Latvian students' performance and school environment in OECD PISA comparison]. Andra Kangro redakcijā. Monogrāiju sērija "Izglītības pētniecība Latvijā" Nr. 11. Rìga: Latvijas Universitātes Pedagoóijas, psihologíjas un mākslas fakultātes Izglìtības pētniecības institūts https://www.ipi.lu.lv/ publikacijas-1/oecd-pisa/

Goren, H., Yemini, M. (2017). Global citizenship education redefined - A systematic review of empirical studies on global citizenship education. International Journal of Educational Research 82 (2017), 170-183.

Huber, J., Reynolds, C. (eds.) (2014). Developing intercultural competence through education. Council of Europe Pestalozzi Series (series ed. Josef Huber), No. 3, Council of Europe Publishing.

Hunter, W. D. (2004). Knowledge, Skills, Attitudes, and Experiences Necessary to Become Globally Competent. [Doctoral dissertation, Lehigh University]. ProQuest.

Hunter, W. D., White, G. P., Godbey, G. C. (2006). What Does It Mean to be Globally Competent? Journal of Studies in International Education, 10(3), 267-285.

Kangro, A. red. (2003). Starptautiskais pilsoniskās izglītibas pētijums Latvijā [International CIVIC Education Study in Latvia]. Rīga: Mācību grāmata, 235 lpp. Monogrāfiju sērija "Izglītības pētniecība Latvijā"; Nr. 4. 
Kymlicka, W. (2003). Multicultural states and intercultural citizens, Theory and Research in Education, vol. 1(2), Sage publications, London, Thousand Oaks and New Delhi, 147-169.

Liu, Y., Yin, Y., Wu, R. (2020). Measuring graduate students' global competence: Instrument development and an empirical study with a Chinese sample, Studies in Educational Evaluation, vol. 67, https://www.sciencedirect.com/science/article/pii/ S0191491X20301632

Menga, Q., Zhua, C., Cao, C. (2017). The Role of Intergroup Contact and Acculturation Strategies in Developing Chinese International Students' Global Competence, Journal of Intercultural communication research, 46(3), 210-226.

Nguyen, W. B. (2018). Global Education: Assets and Challenges for Global Competency in Catholic Schools. [Dissertation Doctor in Education, Loyola Marymount University, Los Angelos, CA, USA]. ProQuest.

O'Loughlin E., Wegimont L. (eds.). Global Education in Europe to 2015. Strategy, policies, and perspectives. Outcomes and Papers of the Europe-wide Global Education Congress Maastricht, The Netherlands $15^{\text {th }}-17^{\text {th }}$ November 2002.

OECD (2019). PISA 2018 Assessment and Analytical Framework. OECD Publishing, Paris, https://doi.org/10.1787/b25efab8-en.

OECD (2020). PISA 2018 Results (Volume VI): Are Students Ready to Thrive in an Interconnected World?, OECD Publishing, Paris, https://doi.org/10.1787/d5f68679-en.

OECD/Asia Society (2018). Teaching for Global Competence in a Rapidly Changing World. http://dx.doi.org/10.1787/9789264289024-net

Recommendations on placing development/global education on school agenda (2015). Education Development Centre (Latvia), Leeds Development Education Centre (United Kingdom), Mondo (Estonia), British Council. http://www.globalaizglitiba.lv/assets/ GlobalaIzglitiba/materiali/e-Recommendations.pdf

Regulations Regarding the State Basic Education Standard and Model Basic Education Programmes (2018). Cabinet of Ministers of Republic of Latvia, https://likumi.lv/ta/en/ en/id/303768

Sahlberg, P., Brown, J. (2017). Schooling and Globalization. In Aloni, N., Wientrob, L. (ed.) Beyond Bystanders. Educational Leadership for a Humane Culture in a Globalizing Reality (pp. 33-46). Rotterdam/Boston/Taipei: Sense Publishers.

Sälzer, C., Roczen, N. (2018). Die Messung von Global Competence im Rahmen von PISA 2018: Herausforderungen und mögliche Ansätze zur Erfassung eines komplexen Konstrukts [Assessing Global Competence in PISA 2018: Challenges and approaches to capture a complex construct ], Z Erziehungswiss 21, 299-316.

Schulz, W., Fraillon, J., Ainley, J. Losito, B., Kerr, D. (2008). International Civic and Citizenship Education Study. Assessment Framework. IEA, Amsterdam.

Schulz, W., Ainley, J., Fraillon, J., Losito, B., Agrusti, G. (2016). IEA International Civic and Citizenship Education Study 2016 Assessment Framework. Springer. https://www. springer.com/gp/book/9783319393568

Schulz, W., Ainley, J., Fraillon, J. et al. (2018). Becoming Citizens in a Changing World. IEA International Civic and Citizenship Education Study 2016 International Report. Springer. https://www.springer.com/gp/book/9783319739625

Torney-Purta, J., Cabrera, J. C., Roohr, K. C., et al. (2015). Assessing Civic Competency and Engagement in Higher Education: Research Background, Frameworks, and Directions for 
Next-Generation Assessment. ETS Research Report No. RR-15-34. (C) Educational Testing Service.

Torres, C. A. (2015). Solidarity and competitiveness in a global context: Comparable concepts in global citizenship education? The International Education Journal: Comparative Perspectives, 14(2), 22-29. Special Edition: ANZCIES Conference Proceedings 2014. http://iejcomparative.org

UNESCO (2015a). Global Citizenship Education. Topics and Learning Objectives.

UNESCO (2015b). Education 2030. Incheon Declaration and Framework for Action for the implementation of Sustainable Development Goal 4. 